\title{
GROUP COMPOSITION AND SEX RATIO IN HANUMAN LANGURS (SEMNopitheCUS ENTELLUS) IN THE ARAVALI HILLS OF RAJASTHAN, INDIA
}

\author{
Anil Kumar Chhangani \\ Primate Research Centre, 396, $3^{\text {rd }}$ 'C'Road, Sardarpura, Jodhpur, Rajashtan 342001, India. \\ Email:chhanganiak@yahoo.com
}

\begin{abstract}
In the present study a total 16 groups of Hanuman Langurs (Semnopithecus entellus), including 11 unimale bisexual troops and five all male bands with a population of 540 animals, were observed at Kumbhalgarh Wildlife Sanctuary in the Aravalli Hills. They were studied for their group size, composition, sex ratio, etc. For this three focal troops BS-2, BS-5 and BS-10 were observed in three different eco-systems. The mean troop size was 41.7 (range 19 to 113 ) and the mean band size was 15.6 (range 8 to 32 ). The adult male-female sex ratio comes to 1: 4.6 in the study area.
\end{abstract}

\section{Keywords}

Hanuman Langur, Semnopithecus entellus, census, group size, focal troops, population, sex ratio, composition, Kumbhlagarh Wildlife Sanctuary (KWS), Aravalli Hills

\section{Introduction}

The Hanuman Langur, Semnopithecus entellus (Primates: Ceropithecidae: Colobine), is the most widely distributed of the 19 non-human primate species found in the Indian subcontinent. It is a highly adaptive species (Roonwal \& Mohnot, 1977; Wolfhemin, 1983; Chhangani, 2000). It is found from the snow clad peaks of the Himalaya (up to about $4100 \mathrm{~m}$ altitude) in the north to Cape Camorin in the south and from the fringe of the great Indian desert in the west to Bengal in the east (Roonwal \& Mohnot, 1977; Mohnot 2001). The Hanuman Langur is largely a deciduous or dry deciduous forest animal and prefers dry tropical forest, scrub jungles and arid rocky area with xerophytic vegetation. Since the natural habitat of the langur is being eroded at a fast pace, its presence near human habitations and religious places is a common sight (Chhangani, 2000). Because of its ruminant-like digestion (Bauchop \& Martucci, 1968), it can utilize a wide variety of food items.
}

Hanuman Langurs live in social groups of various sizes and compositions. There are "unimale bisexual groups" comprised of male infants, juveniles, and females of all ages and an adult male; "multimale bisexual groups" are comprised of males and females of all ages, "all male groups" (all-male band) are comprised of males of all ages except infant or breast feeders. The group size varies from 2-3 to 80-90, or in exceptional cases up to 125 or even more. A "unimale bisexual group" is generally composed of only one adult male, zero to a few sub adult males and females, zero to a few juvenile males and females, several adult females and infants of both sexes. The number of adult males in multimale bisexual groups may vary from one to several; the adult sex ratio being uneven as one male to nine females (average 1:1.8 to 1:5.6) (Winkler, 1981; Newton, 1984; Rajpurohit, 1992; Mohnot, 2001).

\section{Study area}

The Kumbhalgarh Wildlife Sanctuary (KWS) lies between $20^{\circ} 5^{\prime}$ \& $23^{\circ} 3^{\prime} \mathrm{N}$ and $73^{\circ} 15^{\prime} \& 73^{\circ} 45^{\prime} \mathrm{E}$ about $200 \mathrm{~km}$ south of Jodhpur in the west Aravalli hills of Rajasthan, India (Fig. 1). The total area of KWS is $585 \mathrm{~km}$. Its altitude varies from 274 to $1155 \mathrm{~m}$ above sea level. KWS is characterized by distinct winter, summer and monsoon. During summer, temperature fluctuates between $30^{\circ} \mathrm{C}$ and $48^{\circ} \mathrm{C}$. The minimum temperature in winter is $5^{\circ} \mathrm{C}$, which may go down to $2^{\circ} \mathrm{C}$ in December - January. The average annual rainfall is $725 \mathrm{~mm}$, with a minimum $403 \mathrm{~mm}$ and maximum $950 \mathrm{~mm}$. The forest is broadly dry deciduous or woodland type dominated by Kala dhawa (Anogeisus pendula), Gorya dhawa (Anogeissus latifolia), Salar (Boswellia serrata), Godal (Lannea coromandelica), Kherni (Wrightia tinctoria), Dhawa (Anogissus pendula), Kumbat (Acacia Senegal), Khair (Acacia catechu), Ber (Ziziphus mauritiana), Dhonk (Butea monosperma) etc. The undergrowth mainly consists of Jharber (Ziziphus nummularia), Ardusa (Adhatoda zeylanica), Gangan (Grewia tenex), Franger (Grewia flavescens), Kanter (Capparis separaia), Lantana (Lantana camara), etc. Some climbers and grasses are also found. The main fauna of KWS includes Leopard (Panthera pardus), Hyena (Hyaena hyaena), Indian 




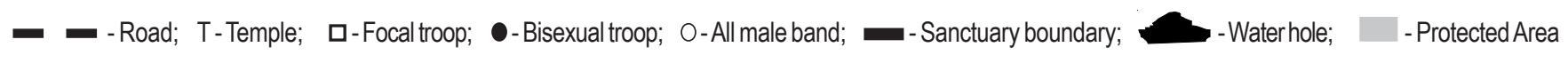

Figure 1. Location of Hanuman Langur troops and bands in Kumbalgarh Wildlife Sanctuary 
Wolf(Canis lupus), Jackal (Canis aureus), Sloth Bear (Melursus ursinus), Four-horned Antelope (Tetracerus quadricornis), Chinkara (Gazella gazella), Porcupine (Hystrix indica), Sambar (Cervus unicolor), Blue Bull (Boselaphus tragocamelus), Toddy Cat (Paradoxorus hermaphroditus), Jungle Cat (Felis chaus), Fox (Vulpes bengalensis), Crocodile (Crocodilus palustris) and Rock Python (Python molurus).

\section{Material and Methods}

The study was initiated in December 1995. During a period of three and half years (up to August, 1999), over 6500 hours of field observations were devoted to this study in an area of $40 \mathrm{sq}$ $\mathrm{km}$ in and around some parts of KWS. More than 4500 hours were devoted to focal troop study and the rest for census, phenology of plants and scat collection. In addition to the annual census of population, groups were followed periodically. Census data was obtained during progressions from one site to another during early mornings and late evenings. Besides, occasional counting was undertaken when troops were at rest in the afternoon. Efforts were made to recognize sex of all individuals including infants and juveniles. The large-sized troops were counted twice or thrice enabling correct identification of young animals. However, there may be some chance of moderate degree of error in determining age classification

Table 1. Census of Hanuman Langur study groups in and around Kumbhalgarh Wildlife Sanctuary

\begin{tabular}{llll}
\hline Locations & 1997 & 1998 & 1999 \\
\hline Filter House & 16 & 18 & 19 \\
Ranakpur Dam & 4 & 5 & 8 \\
Savika Restaurant & 38 & 40 & 43 \\
Near Amba Temple & 34 & 37 & 32 \\
Near Amba Temple (Census 1999) & - & - & 9 \\
AtAmba Temple & 17 & 17 & 18 \\
Forest Naka & 36 & 38 & 42 \\
Ranakpur Maingate & 31 & 34 & 37 \\
Ranakpur Dharamshala & 20 & 24 & 26 \\
Ranakpur Main temple & 24 & 26 & 30 \\
Sun temple & 105 & 110 & 113 \\
Dargah & 9 & 8 & 9 \\
Milestone Malgarh 2km & 80 & 75 & 74 \\
River side & 33 & 34 & 32 \\
River turn & 23 & 21 & 20 \\
Milestone Malgarh 2 km & 27 & 26 & 28 \\
Total & 497 & 513 & 540 \\
\hline
\end{tabular}

especially when the animals confined themselves in tree canopies in the interior of the forest, and individuals who were in the transitional phase, between sub adult and young adult, between juvenile to sub adults and between infants to juvenile phase. In this study, group data was collected on libitum basis as well as by scan and focal sampling methods of Altmann, 1974.

\section{Results}

Annual census carried out at KWS during the study period showed an increasing trend in the Hanuman Langur population. The census of 1997 covering 11 bisexual troops and four all male bands yielded 497 animals. In 1998, this population increased to 513 with a net gain of 16 individuals. In 1999, the population reached to 540 with an increase of 27 individuals (Table 1).

Focal troops: Out of 16 study groups (11 bisexual and 5 bands) three troops were selected as focal troops living in different ecosystems for long-term behavioural study. These three focal troops were living in three different ecological conditions. By and large, the three ecological sets were uniform as far as climate, rainfall, topography, altitude, vegetation, etc. were concerned, but, there were variations in biotic factors like, predation pressure, artificial feeding, cattle grazing, wood cutting, agricultural activity, human settlement, etc. These focal bisexual troops were B-2 located near Savik Restaurant, troop B-5 was located near Ranakpur temple and troop B-10 was found in the interior of the forest of KWS. Factors that influence these troops are as follows:

\begin{tabular}{|c|c|c|c|}
\hline Factors & I & II & III \\
\hline Human interference & Present & Present & Absent \\
\hline Human settlements & Present & Present & Absent \\
\hline Grazing & Allowed & Allowed & Not allowed \\
\hline Tree cutting & Present & Present & Absent \\
\hline Artificial feeding & Absent & Present & Absent \\
\hline Agricultural activity & Present & Absent & Absent \\
\hline Highway traffic & Present & Present & Absent \\
\hline Predators & $\begin{array}{l}\text { Panther, } \\
\text { Jackals, Wolf, } \\
\text { dog, etc. }\end{array}$ & Dogs only & $\begin{array}{l}\text { Panther, } \\
\text { Hyaena, Wolf, } \\
\text { Jackals, etc. }\end{array}$ \\
\hline
\end{tabular}

I - Ecosystem-I - Focal Troop 1 (B-2) Ranakpur Dam;

II - Ecosystem-II - Focal Troop 2 (B-5) Ranakpur main gate

III - Ecosystem-III - Focal Troop 3 (B-10) interior forest

These 16 troops belonged to three different ecosystems. Troops 1-6 belonged to disturbed forest ecosystem; troops 7-11 belonged to temple ecosystem and troops and bands 12-16 were in undisturbed forest ecosystem (Fig. 1).

During June 1999, we found a split in focal troop AMB-2 forming two subtroops AMB-2 and AMB-2a as follows: 


\begin{tabular}{llllllll}
\hline Date & Troop 2 & Alpha & A & YA & SA & Ju & Total \\
\hline June, 1998 & AMB-2 & 2 & 13 & 6 & 9 & 6 & 37 \\
June, 1999 & AMB-2 & 1 & 7 & 6 & 7 & 8 & 32 \\
& AMB-2a & 0 & 5 & 2 & 1 & 1 & 9 \\
\hline
\end{tabular}

A - adult; YA - young adult; SA - subadult; Ju - juvenile

Composition of focal troops: For better understanding of troop structure, all the three focal troops were studied for their composition during the study period.

Details of the study troops B-2, B-5 and B-10 are given in Table 2.

\section{Discussion}

The census and social organisation studies conducted at KWS revealed a clear-cut existence of unimale bisexual and all-male pattern, which constitute the langur population. The same situation prevails in Jodhpur langur population as found in the last three decades. According to 1999 census at KWS based on 16 groups, $68.75 \%$ troops were unimale and $31.25 \%$ were all male and $28.4 \%$ all-male bands. About $150 \mathrm{~km}$ from KWS, the langur population at Mt. Abu was comprised of $86 \%$ unimale and $16 \%$ male bands observed by Hardy (1977). Likewise, in Madhav National Park, $71.4 \%$ were unimale and $28.5 \%$ were male bands in 14 troops surveyed by Kankane (1984).

Kumbhalgarh, Jodhpur, Mt. Abu and Kanha are unimale troop habitats. There are habitats in India which represent only the multimale troops, like Kaukori and Orcha (Jay, 1963), Bhimtal (Vogel, 1971) and Shimla (Sugiyama, 1976). In Nepal, at Melemchi (Bishop, 1975, 1979) and at Sukhumbu (Boggess, 1979), the groups were mostly multimale.

The population status and its fluctuation depend mainly on births, deaths and immigration in troops and bands. There appears to be some variation in troop composition from one habitat to another. The mean troop size at KWS was 41.72 (range, 19-113). Mean troop size of other areas are: Sariska, Rajasthan 64 (range 30-125) and Bhimtal (Kumaon Hills) 23 (range 15-30) (Vogel, 1971, 1973); Kanha 21 (range 15-30) (Newton, 1987); Gir forest, Gujarat 30 (range 16-48) (Rahman, 1973); Madhav National Park 21.2 and 21.7 (range 8-37) (Kankane, 1984); Ramnagar, Nepal 18.3 (range 6-41) (Koenig et al., 1998); and Jodhpur, Rajasthan 44.9 (range 6-129) (Mohnot 1999).

The sex ratio in Hanuman Langur varies greatly from place to place and year to year. Comparison of data from several field sites (Sugiyama, 1964; Jay, 1965; Yoshiba, 1968; Mohnot, 1974; Newton, 1984; Agoramoorthy, 1987; Rajpurohit, 1987; Srivastava, 1989; Mohnot 1999; present study) suggests that the sex ratio in Hanuman langurs in female biased.

\section{Acknowledgement}

This study is a part of Indo-US Primate Project, a collaborative programme of the Ministry of Environment and Forests, Government of India, and the U.S. Fish \& Wildife Service. (Grant

Table 2. Composition of focal troops B-2, B-5 and B-10

\begin{tabular}{|c|c|c|c|c|c|c|c|c|c|c|c|c|c|}
\hline \multirow[t]{2}{*}{ Year } & \multirow{2}{*}{\multicolumn{2}{|c|}{ Adult }} & \multicolumn{2}{|c|}{ Sub adult } & \multicolumn{2}{|c|}{ Juvenile } & & \multicolumn{4}{|c|}{ Infants } & \multirow[b]{2}{*}{ Total } \\
\hline & & & M & $F$ & M & $F$ & $\begin{array}{l}\text { WC } \\
\text { M }\end{array}$ & $F$ & $\begin{array}{l}\mathrm{CC} \\
\mathrm{M}\end{array}$ & $F$ & $\begin{array}{l}\mathrm{BC} \\
\mathrm{M}\end{array}$ & $F$ & \\
\hline \multicolumn{14}{|c|}{ Troop B-2 } \\
\hline 1997 & 1 & 15 & 0 & 0 & 0 & 2 & 7 & 4 & 2 & 2 & 3 & 2 & 38 \\
\hline 1998 & 1 & 15 & 0 & 3 & 6 & 4 & 3 & 3 & 1 & 1 & 2 & 1 & 40 \\
\hline 1999 & 1 & 18 & 0 & 2 & 5 & 4 & 4 & 3 & 2 & 2 & 1 & 1 & 43 \\
\hline \multicolumn{14}{|c|}{ Troops B-5 } \\
\hline 1997 & 1 & 15 & 0 & 0 & 1 & 2 & 5 & 4 & 0 & 0 & 1 & 1 & 30 \\
\hline 1998 & 1 & 14 & 1 & 2 & 4 & 2 & 4 & 2 & 1 & 0 & 2 & 1 & 34 \\
\hline 1999 & 1 & 15 & 4 & 2 & 3 & 2 & 4 & 3 & 1 & 1 & 1 & 0 & 37 \\
\hline \multicolumn{14}{|c|}{ Troops B-10 } \\
\hline 1997 & 1 & 17 & 0 & 0 & 0 & 2 & 4 & 2 & 2 & 1 & 2 & 2 & 33 \\
\hline 1998 & 1 & 16 & & 2 & 3 & 2 & 3 & 3 & 0 & 1 & 2 & 1 & 34 \\
\hline 1999 & 1 & 16 & 0 & 2 & 0 & 3 & 3 & 4 & 1 & 0 & 1 & 1 & 32 \\
\hline
\end{tabular}

M- male; F - female; WC - white coat; CC - changing coat; BC - black coat infants 
Agreement No. INT/FWS-22). I would like to thank Prof. S.M. Mohnot, Director, Indo-US Primate Project, Dr. Ashok Purohit, Head, Department of Zoology, J.N.V. University., the State Forest Department staff and officials of Kumbhalgarh Wildlife Sanctuary, especially A.C.F. Shri Lalit Singh Ranawat and Shri Sukhdave and Shri Madan Mali, Field Assistants for their support during this field study.

\section{References}

Agoramoorthy, G. (1987). Reproductive Behaviour in Hanuman Langur, Presbytis entellus. Ph.D. Thesis, Jodhpur University.

Altmann, J. (1974). Observational study of behaviour: sampling methods. Behaviour 49: 227-267.

Bauchop, T. and R. Martucci (1968). Ruminent like digestion of langur monkey. Science 161: 698-699.

Bishop, N.H. (1975). Social behaviour of langur monketys (Presbytis entellus) in high altitude environment. Unpublished Ph.D. Dissertation, University of California at Berkeley.

Bishop, N.H. (1979). Himalayan langures: Temperate colobines. Journal of Human Evolution 8: 251-281.

Boggess, J. (1979). Troop male membership and infant killing in langurs (Presbytis entellus). Folia Primatology 32: 65-107.

Chhangani, A.K. (2000). Eco-behavioural diversity of langurs (Presbytis entellus) living in different eco systems. Ph.D. thesis, JNV University, Jodhpur.

Hardy, S.B. (1977). The Langurs of Abu: Female and Male Strategies of Reproduction. Harvard University Press, Cambridge.

Jay, P. (1963). Mother infant relations in langurs. In: Maternal Behaviour in Mammals. BHL Rheingold, New York.

Jay, P. (1965). The Common Langur of north India, pp 197-249. In: DeVore, I. (Editor) Primate Behaviour. Field Studies of Monkeys and Apes. Holt Rinehart and Winston, New York, .

Kankane, P.L. (1984). Studies on the Hanuman Langur, P. entellus at the Madhav National Park, Shivpuri (Madhya Pradesh, India). pp. 23 31. In: Roonwal, M.L., S.M. Mohnot and N.S. Rathore (Editors) Current Primate Researches. Jodhpur, Jodhpur University Press.

Koenig, A., J. Beise, M.K. Chalise and J.U. Ganzhorn (1998). When females should contact for food testing hypotheses about resource density, distribution, size and quality with Hanuman langur (P. entellus). Behavioural Ecology and Sociobiology 42: 225-237.

Mohnot, S.M. (1974). Ecology and Behaviour of the Common Indian Langur Presbytis entellus. Ph.D. Thesis, University of Jodhpur, Jodhpur. Mohnot, S.M. (1999). Annual Report year 5: August 1998 to July 1999. Indo-US Primate Project, Department of Zoology, JNV University, Jodhpur. P. (1-69)

Mohnot, S.M. (2001). Sociology of the Hanuman Langur, Semnopithecus entellus in the wild. The fourth Dr. M.L. Bhatia Memorial Lecture-2000 Department of Zoology, University of Jodhpur, Jodhpur.

Mohnot S.M., G. Agoramoorthy, L.S. Rajpurohit and A. Srivastava (1987). Ecobehavioural studies of Hanuman Langurs, Presbytis entellus,
Technical Report, 1983-86, MAB-DoEn. New Delhi, Government of India,.

Newton, P.N. (1984). The ecology and social organization of Hanuman langurs (Presbytis entellus Dufresne, 1797) in Kanha Tiger Reserve, Central Indian Highlands. Ph.D. Thesis, University of Oxford.

Newton, P.N. (1987). The social organization of forest Hanuman Langurs (Presbytis entellus). International Journal of Primatology 8: 199-232.

Parthasarthy, M.D. (1977). Ecology and Ethology of Hanuman Langur (Presbytis entellus) and the Bonnet Macaque (Macaca radiata), pp. 46-51. In: Prasad, M.R.N. and T.C. Anand Kumar (Editors) Use of Non-human Primates in Biomedical Research. Indian National Science Academy.

Rahman, H. (1973). The langurs of Gir Sanctuary (Gujarat) - A preliminary survey. Journal of Bombay Natural History Society 70: 194-314.

Rajpurohit, L.S. (1987). Male Social Organisation in Hanuman langur (Presbytis entellus). Ph.D. Thesis, University of Jodhpur, Jodhpur.

Rajpurohit, L.S. (1992). Mother-infant bond and dead infant carrying behaviour of female langurs, Presbytis entellus, p. 216. Abstracts-XIVth Congress of the International Primatological Society, August 1992, Strasbourg,

Rajpurohit, L.S. and A.K. Chhangani (1997). Males number decreasing in Langurs (P. entellus) around Jodhpur (India). Primate Report Special Issue 48(2): 30.

Roonwal, M.L. and S.M. Mohnot (1977). Primates of South Asia: Ecology, Sociobiology, and Behaviour. Harvard University Press, Cambridge, xviii+421pp.

Srivastava, A. (1989). Feeding Ecology and Behaviour of Hanuman langur, Presbytis entellus. Ph.D. Thesis. Univ. of Jodhpur.

Sugiyama, Y. (1964). Group composition, population density and some sociology observations of Hanuman Langurs (Presbytis entellus). Primates 5: 7-37.

Sugiyama, Y. (1976). Characteristics of the ecology of the Himalayan langurs. Journal of Human Evolution 5, S. 249-277.

Sugiyama, Y., Y. Kenji and M.D. Parthasarathy (1965). Home range, mating season, male group and intertroop relations in hanuman langurs (Presbytis entellus). Primates 6, S. 73-106.

Vogel, C., (1971). Behavioural differences of Presbytis entellus in two different habitats. Proceedings of the $3^{\text {rd }}$ International Congress of Primatology 3: 41-47.

Vogel, C. (1973). Acoustical communication among free ranging common Indian Langur (Presbytis entellus) in two different habitats of North India. American Journal of Physical Anthropology 38: 469-479.

Winkler, P. (1981). Zur oko-ethologie freilebender Hanuman Languren (Presbytis entellus entellus Dufresne, 1797) in Jodhpur (Rajasthan), Indien. Ph.D. Dissertation, University of Gottingen, Germany

Wolfheim, JH, (1983). Primates of the World: Distribution, Abundance and Conservation. University of Washington Press, Seattle.

Yoshiba, K. (1968). Local and inter-troop variatbility in ecology and social behaviour of common Indian Langurs, pp. 217-242. In: Jay, Primates. Holt, Rinehart \& Winston, New York. 